\title{
Low serum ferritin and G6PD deficiency as potential predictors of anaemia in pregnant women visiting Prime Care Hospital Enugu Nigeria
}

\author{
Godwill Azeh Engwa ${ }^{{ }^{*}} \mathbb{D}$, Marcellus Unaegbu', Marian N. Unachukwu², Mary-Gloria C. Njoku³, \\ Kingsley N. Agbafor ${ }^{4}$, Wilfred Fon Mbacham ${ }^{5}$ and Anthony Okoh ${ }^{6}$
}

\begin{abstract}
Objectives: Though iron deficiency is known to be a major risk factor of anaemia, the association of G6PD deficiency and malaria with anaemia still remains unclear. Hence, a cross-sectional study involving 95 pregnant women visiting Prime Care Hospital in Trans-Ekulu region of Enugu Nigeria was conducted to determine possible predictors of anaemia in pregnancy.

Results: The prevalence of anaemia, malaria and G6PD deficiency were 53.7, 12.6 and $60 \%$ respectively. Low serum ferritin (OR 5.500, Cl 2.25-13.42, $p<0.05)$ and G6PD deficiency (OR 0.087, Cl 0.03-0.23, $p<0.05)$ were associated with anaemia in pregnancy. On the other hand, malaria did not significantly associate (OR 1.184, Cl 0.35-3.97, $p=0.964)$ with anaemia in pregnant women. These findings showed high prevalence of anaemia among pregnant women with low serum ferritin level and G6PD deficiency as high risk factors of anaemia.
\end{abstract}

Keywords: Anaemia, Malaria, Pregnancy, G6PD deficiency, Serum ferritin, Haemoglobin concentration

\section{Introduction}

Globally, anaemia affects about 2 billion people of which over 800 million are children and pregnant women particularly in Africa and Asia [1, 2]. Of the estimated 1 million yearly deaths in Africa and South-East Asia, anaemia is reported to account for about 75\% [3]. Anaemia in pregnancy is even more prominent in developing countries with an estimated prevalence ranging from about 56 to $61 \%$ [4]. It is estimated to be responsible for about $20 \%$ of maternal death in sub-Sahara Africa [5].

Anaemia is characterized by low haemoglobin $(\mathrm{Hb})$ concentration in blood below the normal level [6]. Iron is a major and essential component of $\mathrm{Hb}$ affix in the porphyrin ring mainly to bind oxygen molecules thereby

\footnotetext{
*Correspondence: engwagodwill@gmail.com; gengwa@gouni.edu.ng ${ }^{1}$ Biochemistry, Department of Chemical Sciences, Faculty of Natural and Applied Sciences, Godfrey Okoye University, P.M.B 01014, Thinkers Corner, Enugu, Nigeria

Full list of author information is available at the end of the article
}

facilitating its distribution in the body which is required for cellular respiration and other cell functions [7]. Iron is stored in the form of ferritin which is an intracellular protein containing about 4000-4500 iron atoms, thus serves as iron store in the body [8]. Low serum ferritin level in the body has been shown to be associated with iron deficiency and eventually anaemia [9]. Apart from iron level and serum ferritin in blood, glucose 6 phosphate dehydrogenase (G6PD) deficiency [10] and malaria [11] are other factors of concern. Deficiency of G6PD enzyme results in decrease level of reduced glutathione (GSH) thus making the red blood cells (RBCs) vulnerable to oxidative damage and eventually haemolysis or anaemia [12]. Malaria during pregnancy is among the most common complications of pregnancy and highly prevalent in sub-Sahara Africa [13]. In malaria-endemic areas, especially sub-Sahara Africa, about $25 \%$ of pregnant women are estimated to be infected with malaria parasite [14]. Though most malaria infections in pregnant women 
may be asymptomatic, the resultant anaemia may be fatal [15] constituting a major risk of anaemia in pregnancy.

Though serum ferritin and malaria are well documented as potential risk factors of anaemia in pregnancy, limited data is available on the contribution of G6PD deficiency with other predictors of anaemia in pregnancy.

\section{Main text \\ Methods \\ Study area/participants}

This pilot study was carried out among pregnant women attending anti-natal care (ANC) at Prime Care hospital, Trans-Ekulu, Enugu, Nigeria. Prime care hospital is located in Enugu East local government area of Enugu with coordinates: $6^{\circ} 27^{\prime} 9.60^{\prime \prime} \mathrm{N} 7^{\circ} 30^{\prime} 37.20^{\prime \prime} \mathrm{E}$.

\section{Study design and inclusion criteria}

This cross sectional study involved pregnant women of all trimester visiting ANC from April to May, 2015 who had not received any therapy for anaemia or iron supplement, not severely ill, no complications and are willing to participate were considered for inclusion and consecutively recruited for the study.

\section{Sample collection and analysis}

Five millilitre of venous blood was collected into EDTA tubes to estimate the $\mathrm{Hb}$ level, pack cell volume (PCV), RBC count, and mean cell haemoglobin (MCV) using haematological analyser CELL DYN 1800, Abott Laboratories Diagnostic Division, USA. Thin and thick blood films were prepared, incubated with $10 \%$ Giemsa stain by Sigma-Aldrich Germany for $10 \mathrm{~min}$ then examined microscopically for the presence of malaria parasite using Model 3000FF microscope by Fisher Scientific, USA. Serum ferritin level was determined according to the method of Worwood and collaborators [16]. The methaemoglobin reduction test of Brewer et al. [17] was used for the determination of G6PD deficiency.

\section{Data and statistical analysis}

Anaemia in pregnancy was defined as $\mathrm{Hb}$ less than $11 \mathrm{~g} /$ $\mathrm{dL}$ and further classified as mild, moderate, and severe anaemia with $\mathrm{Hb}$ measurement between 10.0 and $10.9 \mathrm{~g} /$ $\mathrm{dL}, 7.0$ and $9.9 \mathrm{~g} / \mathrm{dL}$ and less than $7.0 \mathrm{~g} / \mathrm{dL}$ respectively. For the MCV, anaemia was defined as $<80 \mathrm{fL} /$ cell while no anaemia or normal $\geq 80 \mathrm{fL} /$ cell. A PCV of less than $30 \%$ was considered as anaemia while a PCV greater than or equal to $30 \%$ was considered normal. RBC count of less than 3.2 million $/ \mathrm{mm}^{3}$ was defined as anaemia and above 3.2 million $/ \mathrm{mm}^{3}$ was considered normal. Anaemia as defined by serum ferritin was considered at less than $30 \mu \mathrm{g} / \mathrm{L}$ while above $30 \mu \mathrm{g} / \mathrm{L}$ was normal.

The data was analysed using statistical package for social sciences (SPSS) version 16 and presented in tables. Frequencies and proportions of categorical variables were compared with Chi square tests for association. Predictive factors of anaemia were considered as the independent variables and anaemia as the dependent variable to determine the correlation coefficient $(r)$ and significance by Pearson correlation. Logistic regression was employed to determine the odd ratio (OR of the various predictive factors of anaemia. Confidence interval (CI) was taken at $95 \%$ and significant differences were considered at $\mathrm{p} \leq$ 0.05 .

\section{Results \\ Baseline characteristics of pregnant women}

As shown in Table 1, 95 pregnant women enrolled in the study among which 37 (38.9\%) were in their first trimester, $35(36.8 \%)$ in their second trimester and $23(24.2 \%)$ in their third trimester. Their ages ranged from 20 to 35 years with a mean of $27.33 \pm 4.21$ years while the most frequent age was 30 years. The $\mathrm{Hb}$ level of the women ranged from 5.5 to $13.5 \mathrm{~g} / \mathrm{dL}$ with a mean of $9.9 \pm 2.04 \mathrm{~g} /$ dL.

\section{Prevalence of anaemia, malaria and G6PD deficiency}

Among the 95 pregnant women, 51 were anaemic with a prevalence of $53.7 \%$ of which $14(14.7 \%)$ was mild, 30 (31.6\%) moderate and 7 (7.4\%) severe anaemia. Malaria

Table 1 Baseline characteristics of the study

\begin{tabular}{|c|c|c|c|c|c|c|c|}
\hline Parameters & Age (years) & $\mathrm{Hb}(\mathrm{g} / \mathrm{dL})$ & PCV (\%) & $\mathrm{RBC}$ (million $/ \mathrm{mm}^{3}$ ) & MCV (fL/cell) & Serum ferritin $(\mu \mathrm{g} / \mathrm{L})$ & G6PD (\%) \\
\hline Mean & 27.33 & 9.99 & 30.48 & 3.47 & 89.67 & 30.45 & 57.22 \\
\hline Median & 28 & 10.5 & 33 & 3.74 & 90 & 30 & 56 \\
\hline Mode & 30 & 11.5 & 35 & 4 & 90 & 30 & 40 \\
\hline SD & 4.21 & 2.04 & 5.21 & 0.77 & 1.32 & 1.14 & 1.33 \\
\hline Range & 15 & 8 & 17.5 & 2.77 & 84 & 48 & 48 \\
\hline Minimum & 20 & 5.5 & 19.5 & 2.03 & 46 & 10 & 39 \\
\hline Maximum & 35 & 13.5 & 37 & 4.8 & 130 & 58 & 87 \\
\hline
\end{tabular}

SD Standard deviation 
had a prevalence of $12.6 \%(12 / 95)$ while the prevalence of G6PD deficiency was $60 \%$ (57/95).

\section{Association of anaemia with diagnostic parameters}

Anaemia was more prominent in pregnant women of the age group between 20 and 29 years than those between 30 and 39 years but there was no significant correlation between age group and anaemia ( $r$ 0.231, CI 0.12-0.28, $p=0.166$ ). Anaemia in pregnancy was mostly present in the second trimester, followed by the first trimester, and least in third trimester. Anaemia was not associated with the trimester of pregnancy $(r$ 0.184, CI $0.71-0.87$, $p=0.789$ ). Also, the MCV did not correlate with anaemia in pregnancy $(r 0.182,0.25-0.44, p=0.370)$. On the other hand, PCV level was associated with anaemia ( $r 0.875$, CI $0.00-0.03, p<0.05$ ) as most of the women with anaemia had a PCV level below $30 \%$. Similarly, anaemia in pregnancy was associated with RBC count below $3.2 \mathrm{million} / \mathrm{mm}^{3}(r 0.679$, CI $0.00-0.03, p<0.05)$. Results are summarized in Table 2.

\section{Association of anaemia with risk factors (ferritin, malaria and G6PD deficiency)}

Low serum ferritin was associated with anaemia in pregnancy (OR 5.500, CI 2.25-13.42, $p<0.05$ ) as anaemia was not usually present when the serum ferritin level was above $30 \mu \mathrm{g} / \mathrm{L}$, while it was mostly present when serum ferritin level was below $30 \mu \mathrm{g} / \mathrm{L}$. G6PD deficiency correlated with anaemia in pregnancy (OR 0.087, CI $0.03-0.23, p<0.05)$. There was little or no association between malaria and anaemia in pregnant women (OR 1.184 , CI $0.35-3.97, p=0.964)$. The results are summarized in Table 3.

\section{Discussion}

Anaemia in pregnancy remains a problem of public health concern especially in developing countries where it can lead to so many adverse conditions or consequences which can affect the productivity and reproductive capacity of women and also lead to maternal death [18]. The prevalence of anaemia in pregnancy was $53.7 \%$ of which moderate anaemia was the most prevalent $(31.6 \%)$ while severe anaemia was the least (7.4\%). This results fall within the range of previous data reported in developing countries which showed the prevalence of anaemia in pregnancy to range from 35.0 to $75.0 \%$ [19]. Also, previous studies in Nigeria [20-22], Ghana [23] and South East Africa [24-26] have shown the prevalence of anaemia to be in a close range to that found in this study.

One of the main contributing risk factors of anaemia is iron deficiency which accounts for about $50 \%$ of all cases of anaemia [27]. Serum ferritin has been used as a measure for iron deficiency since it serves as iron store in the body [28]. Malaria in pregnancy has also been shown to be characterized by secondary anaemia which is at risk to mother and off-spring [29]. This is as a result of malaria parasite that destroys erythrocytes during cell division and merozoite release [30]. Another risk factor of anaemia is G6PD deficiency whereby a deficiency in

Table 2 Demographic characteristics and predictors of anaemia among pregnant women

\begin{tabular}{|c|c|c|c|c|c|c|c|}
\hline \multirow[t]{2}{*}{ Variables } & \multicolumn{5}{|c|}{ Anaemia status } & \multirow[t]{2}{*}{$r(95 \% \mathrm{Cl})$} & \multirow[t]{2}{*}{$p$ value } \\
\hline & Absent (\%) & Mild (\%) & Moderate (\%) & Severe (\%) & Total & & \\
\hline \multicolumn{8}{|c|}{ Age range (years) } \\
\hline $20-29$ & $25(43.1)$ & $10(17.2)$ & $21(36.2)$ & $2(3.4)$ & 58 & \multirow[t]{2}{*}{$0.231(0.12-0.28)$} & \multirow[t]{2}{*}{0.166} \\
\hline $30-39$ & $19(51.4)$ & $4(10.8)$ & $9(24.3)$ & $5(13.5)$ & 37 & & \\
\hline \multicolumn{8}{|l|}{ Trimester } \\
\hline First & $17(45.9)$ & $7(18.9)$ & $11(29.7)$ & $2(5.4)$ & 37 & \multirow[t]{3}{*}{$0.184(0.71-0.87)$} & \multirow[t]{3}{*}{0.789} \\
\hline Second & $14(40.0)$ & $5(14.3)$ & $12(34.3)$ & $4(11.4)$ & 35 & & \\
\hline Third & $13(56.5)$ & $2(8.7)$ & $7(30.4)$ & $1(4.3)$ & 23 & & \\
\hline \multicolumn{8}{|c|}{ MCV (fL/cell) } \\
\hline 80 & $35(46.1)$ & $11(14.5)$ & $26(34.2)$ & $4(5.3)$ & 76 & \multirow[t]{2}{*}{$0.182(0.25-0.44)$} & \multirow[t]{2}{*}{0.370} \\
\hline 80 & $9(47.4)$ & $3(15.8)$ & $4(21.1)$ & $3(15.8)$ & 19 & & \\
\hline \multicolumn{8}{|l|}{ PCV (\%) } \\
\hline 30 & $44(73.3)$ & $12(20.0)$ & $4(6.7)$ & $0(0.0)$ & 60 & \multirow[t]{2}{*}{$0.875(0.00-0.03)$} & \multirow[t]{2}{*}{0.000} \\
\hline 30 & $0(0.0)$ & $2(5.7)$ & $26(74.3)$ & $7(20.0)$ & 35 & & \\
\hline \multicolumn{8}{|c|}{ RBC (million/mm³) } \\
\hline 3.2 & $42(70.0)$ & $9(15.0)$ & $7(11.7)$ & $2(3.3)$ & 60 & \multirow[t]{2}{*}{$0.679(0.00-0.03)$} & \multirow[t]{2}{*}{0.000} \\
\hline 3.2 & $2(5.7)$ & $5(14.3)$ & $23(65.7)$ & $5(14.3)$ & 35 & & \\
\hline
\end{tabular}

$r$ Pearson correlation coefficient; $\mathrm{Cl}$ confidence interval 
Table 3 Predictors of anaemia in pregnancy

\begin{tabular}{|c|c|c|c|c|c|c|c|c|}
\hline \multirow[t]{2}{*}{ Variables } & \multicolumn{5}{|c|}{ Anaemia status } & \multirow[t]{2}{*}{ OR $(95 \% \mathrm{Cl})$} & \multirow[t]{2}{*}{$r(95 \% \mathrm{Cl} \%)$} & \multirow[t]{2}{*}{$p$ value } \\
\hline & Absent (\%) & Mild (\%) & Moderate (\%) & Severe (\%) & Total & & & \\
\hline \multicolumn{9}{|l|}{ Ferritin $(\mu \mathrm{g} / \mathrm{L})$} \\
\hline 30 & $33(64.7)$ & $8(15.7)$ & $7(13.7)$ & $3(5.9)$ & 51 & $5.500(2.25-13.42)$ & $0.454(0.00-0.03)$ & 0.00 \\
\hline 30 & $11(25.0)$ & $6(13.6)$ & $23(52.3)$ & $4(9.1)$ & 44 & & & \\
\hline \multicolumn{9}{|l|}{ G6PD } \\
\hline Deficient & $14(24.6)$ & $11(19.3)$ & $26(45.6)$ & $6(10.5)$ & 57 & $0.087(0.03-0.23)$ & $0.537(0.00-0.03)$ & 0.00 \\
\hline Non-Deficient & $30(78.9)$ & $3(7.9)$ & $4(10.5)$ & $1(2.6)$ & 38 & & & \\
\hline \multicolumn{9}{|l|}{ Malaria } \\
\hline Present & $6(50.0)$ & $2(16.7)$ & $3(25.0)$ & $1(8.3)$ & 12 & $1.184(0.35-3.97)$ & $0.054(0.93-1.00)$ & 0.964 \\
\hline Absent & $38(45.8)$ & $12(14.5)$ & $27(32.5)$ & $6(7.2)$ & 83 & & & \\
\hline
\end{tabular}

$r$ correlation coefficient, $\mathrm{Cl}$ confidence interval, OR: odd ratio

this enzyme makes erythrocytes to be vulnerable to oxidative damage hence, liable to haemolysis and eventually anaemia [31]. The evaluation of these parameters for association with anaemia showed low serum ferritin (OR 5.5) and G6PD deficiency (OR 0.087) as high risk factor of anaemia. Thus, low serum ferritin or iron deficiency is found to be the most prevalent risk factor of anaemia. This has been confirmed in other studies which have shown iron deficiency to be responsible for anaemia [32] and iron supplementation as a protective measure [33, 34]. G6PD deficiency which had a prevalence of $60 \%$ was also shown to be associated with anaemia. This confirms previous studies which have earlier shown this relationship $[35,36]$. However, malaria which had a prevalence of $12.6 \%$ showed little or no association (OR 1.184) with anaemia in pregnancy and thus not a potential risk factor. This is in contrast to the findings of a study by Matangila and collaborators which showed asymptomatic Plasmodium falciparum infection with a prevalence of about $30 \%$ to be associated with anaemia in pregnancy [37]. It is possible that seasonal variation may have accounted for this difference in malaria prevalence as this present study was carried out between April and May, a period whereby the rainy season was at an early stage in Nigeria compared to the study of Matangila and collaborators which was conducted from July to August deep into the rainy season where malaria transmission was at its peak accounting for the high prevalence and hence association with anaemia. The low prevalence of malaria observed in this study was hence a positive factor that minimized the extent of pregnancy associated anaemia as the presence of malaria is a known predictor of anaemia [38].

In conclusion, anaemia was found highly prevalent in pregnant women attending antenatal care at Prime Care Hospital in Trans-Ekulu region of Enugu Nigeria and was strongly associated with low serum ferritin level and G6PD deficiency as potential risk factors.

\section{Limitations}

This study is a pilot study and was focused on one hospital, thus the small sample size may be limiting to generalize the findings to a large geographic area. Also, the study was carried out between April and May, a period during the rainy season where malaria transmission is not at its peak, thus low prevalence of malaria.

\section{Abbreviations \\ WHO: World Health Organisation; Hb: haemoglobin; G6PD: glucose 6 phos- phate dehydrogenase; GSH: reduced glutathione; RBC: red blood cell; MCV: mean cell volume; PCV: pack cell volume; ANC: anti-natal care; OR: odd ratio; SPSS: statistical package for social sciences; Cl: confidence interval.}

\section{Authors' contributions}

GAE conceived and designed the study along with MU, and AO. GAE carried out the field work and laboratory work along with MU and MNU. WFM, MGCN and GAE were involved in data analysis and interpretation. WFN, AO, MGCN, MNU, KNA and GAE were all involved in drafting the manuscript. All authors read and approved the final manuscript.

\section{Author details \\ ${ }^{1}$ Biochemistry, Department of Chemical Sciences, Faculty of Natural and Applied Sciences, Godfrey Okoye University, P.M.B 01014, Thinkers Corner, Enugu, Nigeria. ${ }^{2}$ Department of Microbiology, Faculty of Natural and Applied Sciences, Godfrey Okoye University, P.M.B 01014, Thinkers Corner, Enugu, Nigeria. ${ }^{3}$ Department of Sociology/Psychology, Faculty of Social and Manage- ment Sciences, Godfrey Okoye University, P.M.B 01014, Thinkers Corner, Enugu, Nigeria. ${ }^{4}$ Department of Biochemistry, Ebonyi State University, P.M.B. 053, Abakaliki, Nigeria. ${ }^{5}$ Laboratory for Public Health Research Biotechnologies, The Biotechnology Centre, University of Yaounde I, BP 8094, Yaounde, Cameroon. ${ }^{6}$ SAMRC Microbial Water Quality Monitoring Centre, Department of Biochem- istry and Microbiology, University of Fort Hare, Alice, South Africa.}

\section{Acknowledgements}

We thank the staff of Prime Care Hospital for the care of the participants and their assistance throughout the study.

\section{Competing interests}

The authors declare that they have no competing interests.

Availability of data and materials

All data generated or analysed during this study are included in this published article and its additional files. 


\section{Consent for publication}

Not applicable.

\section{Ethics approval and consent to participate}

The study design was reviewed and approved by the Local Ethical Institutional Review Board of the Department of Biological Sciences, Godfrey Okoye University, Enugu, Nigeria. Written informed consent was obtained from all pregnant women willing to participant in the study.

\section{Funding}

GAE is grateful to Rev. Fr. Prof. Christian Anieke, the Vice Chancellor of Godfrey Okoye University Enugu and the South Africa Medical Research Council for financial support.

\section{Publisher's Note}

Springer Nature remains neutral with regard to jurisdictional claims in published maps and institutional affiliations.

Received: 20 October 2017 Accepted: 30 November 2017

Published online: 08 December 2017

\section{References}

1. Balarajan Y, Ramakrishnan U, Ozaltin E, Shankar AH, Subramanian SV. Anaemia in low-income and middle-income countries. Lancet. 2011;378:2123-35.

2. WHO. The global prevalence of anaemia in 2011. Geneva: World Health Organization; 2015

3. WHO. Worldwide prevalence of anaemia 1993-2005. WHO global database on anaemia. Geneva: World Health Organisation; 2005.

4. Stevens GA, Finucane MM, De-Regil LM, Paciorek CJ, Flaxman SR, Branca F, et al. Global, regional, and national trends in haemoglobin concentration and prevalence of total and severe anaemia in children and pregnant and non-pregnant women for 1995-2011: a systematic analysis of population-representative data. Lancet Glob Health. 2013;1:E16-25.

5. Tolentino K, Friedman JF. An update on anaemia in less developed countries. Am J Trop Med Hyg. 2007;77:44-51.

6. Steer PJ. Maternal hemoglobin concentration and birth weight. Am J Clin Nutr. 2000:71:1285S-7S

7. Beard JL. Iron biology in immune function, muscle metabolism and neuronal functioning. J Nutr. 2001:131:568S-79S.

8. Worwood M. Ferritin in human tissues and serum. Clin Haematol. 1982:11:275-307.

9. Ogilvie C, Fitzsimons K, Fitzsimons E. Serum ferritin values in primary care: are high values overlooked. J Clin Pathol. 2010;63:1124-6.

10. Pamba A, Richardson ND, Carter N, Duparc S, Premji Z, Tiono A, Luzzatto L. Clinical spectrum and severity of hemolytic anemia in glucose 6-phosphate dehydrogenase-deficient children receiving dapsone. Blood. 2012:120:4123-33.

11. Nosten F, Rogerson SJ, Beeson JG, McGready R, Mutabingwa TK, Brabin B. Malaria in pregnancy and the endemicity spectrum: what can we learn? Trends Parasitol. 2004:20:425-32.

12. Seidman DS, Shiloh M, Stevenson DK, Vreman HJ, Gale R. Role of hemolysis in neonatal jaundice associated with glucose-6-phosphate dehydrogenase deficiency. J Pediatr. 1995;127:804-6.

13. Pamba A, Richardson ND, Carter N, Duparc S, Premij Z, Tiono A, Luzzatto L. Clinical spectrum and severity of hemolytic anemia in glucose 6phosphate dehydrogenase-deficient children receiving dapsone. Blood. 2012;120:4123-33.

14. Schantz-Dunn J, Nour NM. Malaria and pregnancy: a global health perspective. Rev Obstet Gynecol. 2009;2:186-92

15. Agan T, Ekabua J, Udoh A, Ekanem E, Efiok E, Mgbekem M. Prevalence of anemia in women with asymptomatic malaria parasitemia at first antenatal care visit at the University of Calabar Teaching Hospital, Calabar, Nigeria. Int J Womens Health. 2010:2:229-33.
16. Worwood $\mathrm{M}$, et al. Binding of serum ferritin to concanavalin $\mathrm{A}$ : patients with homozygous beta thalassaemia and transfusional iron overload. Br J Haematol. 1980:46:409-16.

17. Brewer GJ, Tarlov AR, Alving AS. Methaemoglobin reduction test: a new, simple, in vitro test for identifying primaquine-sensitivity. Bull World Health Organ. 1960;22:633-40

18. Haas JD, Brownlie TT. Iron deficiency and reduced work capacity: a critical review of the research to determine a causal relationship. J Nutr. 2001:131:676S-88S

19. Omigbodun AO. Recent trends in the management of anaemia in preg nancy. Trop J Obstet Gynaecol. 2004;21(1):1-3.

20. Olatunbosun OA, Abasiattai AM, Bassey EA, James RS, Ibanga G, Anyiekere M. Prevalence of anaemia among pregnant women at booking in the University of Uyo Teaching Hospital, Uyo, Nigeria. BioMed Res Int 2014. https://doi.org/10.1155/2014/849080.

21. Adinma JI, Ikechebelu Jl, Onyejimbe UN, Amilo G, Adinma E. Influence of antenatal care on the haematocrit value of pregnant Nigerian lgbo women. Trop J Obstet Gynaecol. 2002;19:68-70.

22. Idowu OA, Mafiana CF, Sotiloye D. Anaemia in pregnancy: a survey of pregnant women in Abeokuta, Nigeria. Afr Health Sci. 2005:5(4):295-9.

23. Geelhoed D, Agadzi F, Visser L, et al. Severe anemia in pregnancy in rural Ghana: a case-control study of causes and management. Acta Obstet Gynecol Scand. 2006;85:1165-71.

24. Broek NR, Letsky EA. Etiology of anemia in pregnancy in south Malawi. Am J Clin Nutr. 2000;72:S247-56.

25. Hogue M, Kader SB, Hogue E. Prevalence of anaemia in pregnancy in the Uthungulu health district of KwaZulu-Natal, South Africa. S Afr Fam Pract. 2007:49:16-22

26. Hogue AK, Kadar SB, Hogue E, Mugero C. Prevalence of anaemia in pregnancy at Greytown, South Africa. Trop J Obstet Gynaecol. 2006;23:3-7.

27. WHO/UNICEF/UNU. Iron deficiency anaemia: assessment, prevention, and control. Geneva: World Health Organization; 2001.

28. Gordeuk VR, Reboussin DM, McLaren CE, Barton JC, Acton RT, McLaren GD, Harris EL, Reiss JA, Adams PC, Speechley M, Phatak PD, Sholinsky P, Eckfeldt JH, Chen WP, Passmore L, Dawkins FW. Serum ferritin concentrations and body iron stores in a multiethnic primary care population. Am J Haematol. 2008;83:618-26.

29. Menendez C, Fleming AF, Alonso PL. Malaria-related anaemia. Parasitol Today. 2000;16:469-76.

30. Phillips RE, Pasvol G. Anaemia of Plasmodium falciparum malaria. Epidemiol Haematol Dis. 1992;5:315-30

31. Beutler E. G6PD deficiency. Blood. 1994:84:3613-36.

32. Looker AC, Dallman PR, Carroll MD, Gunter EW, Johnson CL. Prevalence of iron deficiency in the United States. J Am Med Assoc. 1997;277:973-6.

33. Menendez C, Kahigwa E, Hirt R, et al. Randomised placebo-controlled trial of iron supplementation and malaria chemoprophylaxis for prevention of severe anaemia and malaria in Tanzanian infants. Lancet. 1997;350:844-50.

34. Menendez C, Todd J, Alonso PL, et al. The effects of iron supplementation during pregnancy, given by traditional birth attendants, on the prevalence of anaemia and malaria. Trans R Soc Trop Med Hyg. 1994;88:590-3.

35. Akanni EO, Oseni BS, Agbona VO, Tijani BA, Tosan E, Fakunle EE, Mabayoje VO. Glucose-6-phosphate dehydrogenase deficiency in blood donors and jaundiced neonates in Osogbo, Nigeria. J Med Lab Diagn. 2010;1:1-4

36. Kaplan M, Hemmerman C. Severe neonatal hyper-bilirubinemia: A potential complication of glucose-6-phosphate dehydrogenase deficiency. Clin Perinatol. 1998;25:575-90.

37. Matangila JR, Lufuluabo J, Ibalanky AL, Luz RA, Lutumba P, Geertruyden JP. Asymptomatic Plasmodium falciparum infection is associated with anaemia in pregnancy and can be more cost-effectively detected by rapid diagnostic test than by microscopy in Kinshasa, Democratic Republic of the Congo. Malar J. 2014:13:132-9.

38. UNDP, WB, WHO. The prevention and management of severe anaemia in children in malaria-endemic regions of Africa: a review of research. Geneva: World Health Organisation; 2001. 